\title{
Somatic Embryogenesis on Plumule and Radicle Explants Obtained from Warm Water Hydroprimed Wheat (Triticum aestivum L.) cv. Kunduru and cv. Cakmak Seeds (Embriogenesis Soma ke atas Plumul dan Radikel Eksplan diperoleh daripada Benih Gandum Air Panas Hidroprim (Triticum aestivum L.) kv. Kunduru dan Cakmak)
}

\author{
PARISA POURALI KAHRIZ \& MAHSA POURALI KAHRIZ*
}

\begin{abstract}
Advances in wheat biotechnology and in vitro somatic embryogenesis (SE) provide new openings to faster application of these techniques in functional genomic studies, genetic engineering and plant breeding. This study reports in vitro SE using plumule and radicle explants of two wheat cultivars Cakmak and Kunduru on MS induction medium amended with varying concentrations of 2,4-D. Both plumule and radicle explants were regenerative and induced variable number of somatic embryos per explant. Explants and treatment methods affected in vitro SE irrespective of the genotypes used in the study. Although 100\% SE was noted on both explants of two cultivars, plumule explants of both genotypes induced heavy and larger friable calli followed by somatic embryogenic calli in terms of weight. Plumule explants also induced large numbers of shoot buds and somatic embryo-induced maturing shoots per explant. The in vitro raised plantlets were successfully rooted followed by hardening and acclimatisation in pots containing peat moss in mist house. After 7 days from weaning, these plants were transferred to a shade house to grow and set flowers. Water spray containing $0.50 \mu \mathrm{g}$ of NPK (1:1:1) was given at intervals of $4 d$ to enhance success rate of acclimatised plants. Success rates of 96 and $80 \%$ were noted on plumule and radicle-induced plants, respectively. It is further concluded that use of this novel methodology would favorably facilitate its use in genetic transformation and functional genomic studies.
\end{abstract}

Keywords: In vitro; plumule; radicle; regeneration; wheat

\section{ABSTRAK}

Kemajuan dalam bioteknologi gandum dan embriogenesis soma (SE) in vitro membuka peluang baru untuk aplikasi pantas teknik ini dalam kajian fungsian genom, kejuruteraan genetik dan pembiakan tumbuhan. Kajian ini melaporkan $S E$ in vitro menggunakan eksplan plumul dan radikel daripada dua kultivar gandum Cakmak dan Kunduru ke atas MS induksi medium in vitro yang dipinda dengan kepekatan berbeza 2,4-D. Kedua-dua eksplan plumul dan radikel telah terjana semula dan mengaruh bilangan pemboleh ubah soma embrio setiap eksplan. Kaedah eksplan dan rawatan mempengaruhi in vitro SE tanpa mengira genotip yang digunakan dalam kajian ini. Walaupun 100\% SE telah dicatat pada kedua-dua eksplan daripada dua kultivar, eksplan plumul dari kedua-dua genotip mengaruh calli yang berat dan lebih besar repui diikuti SE calli daripada sudut berat. Eksplan plumul juga mengaruh sebilangan besar daripada tunas pucuk dan pucuk matang soma embrio-teraruh setiap eksplan. Anak tumbuhan yang ditanam secara in vitro yang telah berjaya berakar umbi diikuti dengan pengerasan dan penyesuaian dalam pasu yang mengandungi mos gambut di rumah kabus. Selepas 7 hari penyapihan, tumbuh-tumbuhan ini telah dipindahkan ke satu rumah peneduh untuk membesar dan mengeluarkan bunga. Semburan air yang mengandungi $0.50 \mu \mathrm{g} N$ NK (1:1:1) telah diberikan pada selang 4 hari untuk meningkatkan kadar kejayaan penyesuaian tumbuh-tumbuhan. Kadar kejayaan 96 dan 80\% dicatat masing-masing ke atas tumbuh-tumbuhan plumul dan radikel. Dapat disimpulkan bahawa penggunaan kaedah novel ini akan menggalakkan kemudahan penggunaannya dalam transformasi genetik dan kajian fungsian genom.

Kata kunci: Gandum; in vitro; plumul; radikel; penjanaan semula

\section{INTRODUCTION}

Wheat (Triticum aestivum L.) is one of the most important globally known food grain cereals. Development of transformation techniques has become one of the focal issues in wheat tissue culture and is becoming an important vehicle in wheat breeding programs throughout the world. It is making use of development of haploids, organogenesis, somatic embryogenesis, selection of somaclonal variants and production of transgenic plants for wheat improvement (Becker et al. 1994; Bi et al. 2007; Chu et al. 1990; Elena \& Ginzo 1988; Fellers et al. 1995; Maddock et al. 1983; Patnaik et al. 2006; Rajyalakshmi et al. 1991; Sarker \& Biswas 2002; Weeks et al. 1993). Previous reports suggested the effects of culture medium and its supplements (Mathias \& Simpson 1986) tissue (Vasil 1994) and genotype (Hess \& Carman 1998) on tissue culture of wheat. In vitro somatic embryogenesis and organogenesis are important applications among 
many biotechnology techniques in genetic improvement (Santacruz-Ruvalcaba et al. 1998). Integration of these techniques with conventional breeding could facilitate breeding activities. Despite many successful regeneration reports in wheat, there is scope of integration of new approaches that can facilitate their usage in breeding and production of transgenic plants (Patnaik \& Khurana 2001). There is a need to fine tune existing and establish new multiplication protocols for rapid, new and reliable in vitro propagation of commercial wheat cultivars (Fennel et al. 1996). This study aimed to design, optimise and establish conditions for an accelerated in vitro propagation system using mature wheat plumule and radicle explants.

\section{MATERIALS AND METHODS}

The seeds of bread wheat cv. Kunduru and Cakmak were obtained from the Department of Agricultural Research, Ministry of Food Agriculture and Livestock, Yenimahalle, Ankara, Turkey. The seeds were pretreated for $3 \mathrm{~min}$ with ethanol followed by surface sterilisation using $50 \%$ commercial bleach (Ace, Turkey) for $30 \mathrm{~min}$ and rinsed $7 \times 4$ min with sterilised distilled water.

Thereafter, the seeds were hydroprimed in 200-250 $\mathrm{mL}$ of sterilised distilled water for $120 \mathrm{~min}$ and incubated at $35 \pm 1^{\circ} \mathrm{C}$ in a water bath for easy removal of mature seed embryos. These seeds were excised under aseptic conditions in a laminar flow cabinet with the help of high quality cutting edge Scalpel Blades No. 10 A (Ted Pella Inc. USA) under Zeiss Stereo Discovery V8 fluorescence dissection microscope to separate zygotic embryos from the seeds; taking care that they should not damage explants and must not include parts of coleoptile with them. Visible plumules and radicles (Figure 1) were isolated from embryos and cultured on MS regeneration medium (Murashige \& Skoog 1962) containing 1, 2, 3, 4, 5 and $6 \mathrm{mg} / \mathrm{L} \mathrm{2,} 4$ - D supplemented with $3 \%(\mathrm{w} / \mathrm{v})$ sucrose (Sigma Aldrich, St Lo Mo USA) and solidified with $0.65 \%$ (w/v) agar (Duchefa, the Netherland). The cultures were incubated at $24 \pm 1^{\circ} \mathrm{C}$ in darkness for 10 days followed by a second subculture of 10 days under the same conditions and a third subculture also of 10 days under $16 \mathrm{~h}$ light (42 $\mu \mathrm{Mol}$ photons m-2s-1) photoperiod for conversion and maturation of embryos.

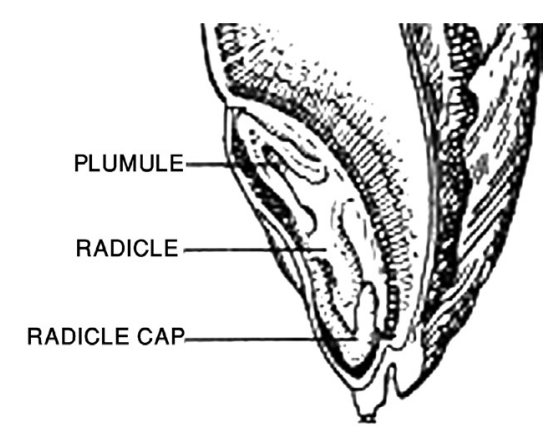

FIGURE 1. Schematic representation of plumule and radical explants of wheat
All culture media were autoclaved after adjusting the $\mathrm{pH}$ to $5.7 \pm 0.1$. Each of the media was prepared in $200 \mathrm{~mL}$ bottles and sterilised by autoclaving at $104 \mathrm{kPa}, 121^{\circ} \mathrm{C}$ for $20 \mathrm{~min}$. Each treatment contained 60 explants divided into 6 replications. Each replication was made up of a single glass Petri dish $(10 \times 100 \mathrm{~mm})$ containing $35 \pm 1 \mathrm{~mL}$ of culture medium and ten (10) explants cultured in each Petri dish. All cultures were incubated at $25 \pm 1{ }^{\circ} \mathrm{C}$ in $16 \mathrm{~h} \mathrm{light}$ (35 $\mu \mathrm{mol} \mathrm{m} \mathrm{m}^{-2} \mathrm{~s}^{-1}$ ) photoperiod provided by cool day light fluorescent lamps (Osram L 18W/765 - Russia). The mature rooted plantlets were transferred to 2 L pots containing 1.75 $\mathrm{L}$ sterilised peat moss in each pot and maintained under $80 \%$ relative humidity and PPFD light intensity of $35 \mu \mathrm{mol}$ $\mathrm{m}^{-2} \mathrm{~s}^{-1}$ in a mist house. Relative air humidity was gradually reduced to $40 \%$ in 7 days time. Peat moss used in the study was prepared locally from leaves. It had $\mathrm{pH}$ of 6.2 and EC of $0.15 \mathrm{dS} \mathrm{m}-1$, porosity of about $(63 \% \mathrm{v} / \mathrm{w})$, that allowed for high water absorption with low bulk density of 0.01 $\mathrm{mg} \mathrm{m}^{-3}$.All acclimatised plants were transferred to a shade house thereafter to observe morphological changes if any and fertility status of in vitro grown plants under ambient conditions of temperature and relative humidity.

\section{STATISTICAL ANALYSIS}

Statistical analysis was performed using One Way ANOVA of IBM SPSS 20 computer statisitical software. The means were compared using Duncan's Multiple Range Test. All values given in percentage were arcsine transformed before subjecting them to statistical analysis (Snedecor \& Cochran 1967).

\section{RESULTS}

\section{CALLUS REGENERATION AND FRESH CALLUS WEIGHT OF TWO EXPLANTS OF BOTH CULTIVARS}

Both plumule and radicle tissues initiated callus induction depending on plant species and concentration of 2, 4-D used in the study by rapid division of somatic tissues. Two explants of both cultivars were regenerative with varying potential, as was reflected by significantly different rates of conversion from induced callogenesis to morphogenesis and plantlet formation.

These continued to grow in mass and weight after the second subculture until they stopped further multiplication of cells in the third subculture, when they started to show visible embryogenic structures on calli.

Similar cell proliferation and callus induction was noted on plumule and radicle explants of cv. Kunuduru after 3-5 and 3-6 days, respectively, such that actively dividing cells doubled their volume in the next $3-5$ days. The growing calli induced further mass and weight after the second subculture. The calli were further subcultured after 10 days; thereafter, they started to show morphogenesis and embryogenic structures on calli.

Induction of callus tissues and cell proliferation was visible after 4-5 days of culture on plumule and 5-6 days 
of culture on radicle explant in cv. Cakmak such that actively proliferating cells hexapulated in volume and had attained a large mass at the start of the second subculture. Light had positive effects resulting in accelerated morphogenesis with induction of nodular embryonic structures with chlorophyll pigmented areas on the bipolar nodular structures/somatic embryos. These modular segments turned up to shoot initials that subsequently expanded to leaves and roots which were noted after 6-8 and 7-9 days during the third subculture on cv. Cakmak and cv. Kunduru based explants that continued to grow. These grew yellowish-white nodular clusters. Some of these were singular and the others were fused together. Thereafter, the growing somatic embryo based seedlings were separated from mother tissue with a slight touch and cultured into separate Magenta boxes for growth. Once the plants grew to $8-9 \mathrm{~cm}$ they were transferred to peat moss and acclimatised in a growth chamber. These plants that grew from plumule and radicle explants of both cultivars appeared phenotypically similar to normal plants and set fertile flowers with seeds. All seeds were viable with ability to germinate and grow to a complete plant.

The in vitro competence of both explants of two wheat cultivars was evaluated according to their morphogenetic behavior and their transformation from somatic embryos to plantlets efficiency. Both cultivars had remarkable competence for induction of callus followed by morphogenesis or induction of nodular somatic embryos. Two explants of both cultivars induced callus identically after exposure to $2,4-\mathrm{D}$ and $100 \%$ callus proliferation was noted on both explants of two cultivars on the regeneration media within 3-7 days of induction and all of these calli were morphogenetic after the third subculture. No callus induction was noted on $1 \times$ MS medium used as control. Irrespective of cultivar and explant all concentrations of 2,4-D used in the study were favorable for induction of light yellow green colored embryogenic callus masses. Somatic embryo based green shoot buds were clearly visible after 12-14 days and 15-17 days on plumule and radicle explants of cv. Cakmak and cv. Kunduru, respectively. Most of the embryos had unicellular origin except for a few with multicellular origin. Unicellular embryos had coordinated cell divisions; whereas, multicellular embryos were fused and connected to the maternal tissues by a suspensor-like structures. They were soft and induced small pre torpedo structures interconnected with thin cell layer made connecting walls after 19-20 days of culture. Fused masses 4-5 embryos were also noted but rarely. These calli induced globular and heart shaped embryo like structures initially. Most of these structures soon converted to pre and post torpedo somatic embryonic bodies with fluffy root hairs. However, some soft embryos on these calli oxidised leading to necrosis after 28 to 30 days of culture without conversion from embryos to plantlets; which were discarded. Irrespective of cv. and explant somatic embryo fusion was more prominent at $1,2 \mathrm{mg} / \mathrm{L}$ 2,4-D concentration in the culture medium. All calli when exposed to light (after third subculture), the morphogenetic nodes started induction of green shoots on both type of explants of two genotypes spanning to 5-6 weeks after culturing of explants and production peak in the 7-9 weeks after culture.

Furthermore, plumule explant of cv. Cakmak induced maximum and statisitically similar fresh callus weight on MS medium containing 1, 5 and $6 \mathrm{mg} / \mathrm{L} \mathrm{2,4-D} \mathrm{(Table}$ 1). Radicle explant of cv. Cakmak, stimulated maximum fresh callus weight on MS medium containing 1,2 5 and $6 \mathrm{mg} / \mathrm{L} 2$,4-D. Whereas, maximum fresh callus weight on plumule explant of cv. Kunduru was noted on MS medium containing $6 \mathrm{mg} / \mathrm{L} 2,4-\mathrm{D}$. The rest of 2,4-D concentrations $(1,2,3,4$ and $5 \mathrm{mg} / \mathrm{L})$ in MS medium induced significantly low fresh callus weight on plumule explant. Contrarily, maximum fresh callus weight on radicle explant of the same cultivar was noted on $1 \mathrm{mg} / \mathrm{L} 2,4-\mathrm{D}$. It was closely followed by statistically similar fresh callus weight induced on MS medium containing $6 \mathrm{mg} / \mathrm{L} \mathrm{2,4-D}$. The rest of 2,4-D concentrations in MS medium induced variable and significantly lower fresh callus weight.

The mean fresh callus weight ranged from 249.80$463.40 \mathrm{mg}$ and $347.10-454.80 \mathrm{mg}$ on plumule and radicle explants of cv. Cakmak, respectively. Mean fresh callus weight of cv. Kunduru ranged from 303.00-526.40 mg on plumule and $287.80-438.90 \mathrm{mg}$ on radicle explants, respectively. The results clearly showed that both explants of cv. Cakmak had an edge over cv. Kunduru for inducing fresh callus weight irrespective of the concentration of 2,4-D used in the experiment. This points out that the gain in fresh callus weight was cultivar and explant specific. Maximum fresh callus weight was obtained on MS medium containing $6 \mathrm{mg} / \mathrm{L} \mathrm{2,4-D} \mathrm{on} \mathrm{plumule} \mathrm{explant} \mathrm{and} 5 \mathrm{mg} / \mathrm{L}$ 2,4-D on radicle explant in cv. Cakmak. Maximum fresh callus weight in cv. Kunduru on plumule and radicle was observed on MS medium containing $5 \mathrm{mg} / \mathrm{L}$ 2,4-D and $2 \mathrm{mg} / \mathrm{L}$ 2,4-D, respectively. The increase in fresh callus weight of both cultivars and explants was largely inconsistent. However, genotypic factor seemed to be operating in response to 2,4-D concentrations.

\section{NUMBER OF SOMATIC EMBRYO INDUCED MATURING SHOOT BUDS PER EXPLANT}

After the third subculture, both cultivars and explants showed significantly improved number of somatic embryos $(p \leq 0.01)$ with fluctuating values on different concentrations of 2,4-D. Explicitly speaking rate of morphogenesis on plumule of both cultivars was reflected on the following regeneration efficiency. However, plumule explants were more favorable to morphogenesis compared to radicle explants.

The somatic embryos bearing calli splitted on slight touch with forceps at maturity and had inclination towards regenerating green shoot buds after 22-25 days. Variable number of visible somatic embryos with shoot buds were noted on calli of two explants of both cultivars (Figure 2(a) \& 2(b)). The number of converted shoot buds (on embryos) per plumule and radicle explant of cv. Cakmak 


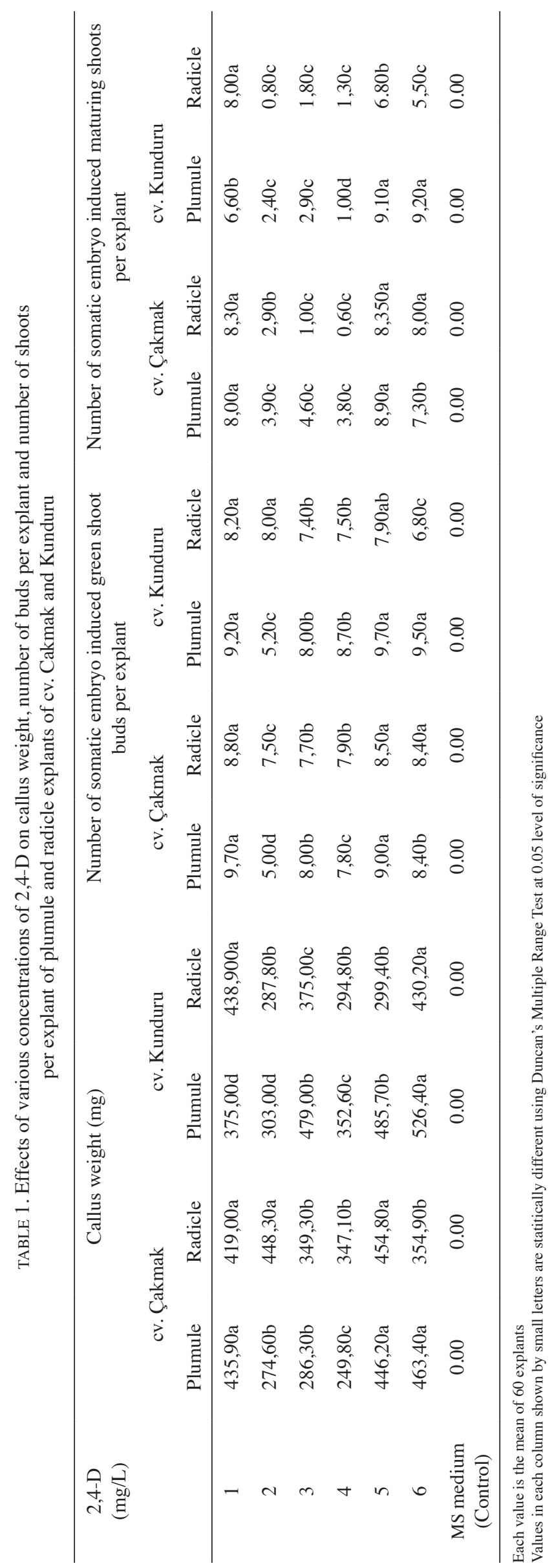


ranged from 5.00-9.70 and 7.50-8.80, respectively. Number of shoot buds on cv. Kunduru plumule and radicle explant ranged 5.2-9.70 and 6.80-8.20, respectively.

Most of these buds matured and developed into shoots after six weeks of culture. These somatic embryo induced maturing shoots were noted on both explants of two cultivar used in the study. Somatic embryo induced maturing shoots increased variably. Generally, the minimum concentration of $(1,2 \mathrm{mg} / \mathrm{L}) 2,4-\mathrm{D}$ were inhibitory in terms of shoot growth (length). Irrespective of the type of explant high concentrations of $2,4-\mathrm{D}(6 \mathrm{mg} / \mathrm{L})$ were promotory in terms of shoot length. The shoot growth on 1, 2, 3 and $4 \mathrm{mg} / \mathrm{L}$ 2,4-D of plumule explant cv. Cakmak and Kunduru never exceeded $1-1.5 \mathrm{~cm}$ in length (data not shown). Rest of the two concentrations ( 5 and $6 \mathrm{mg} / \mathrm{L}$ ) of 2,4-D induced longer shoots $(6-8 \mathrm{~cm})$ on MS medium. Most of the shoots regenerated on embryos also induced roots and had no difficulty in case of plumule explant of cv. Cakmak and radicle explant of cv. Kunduru.

The number of somatic embryo induced maturing shoots per plumule and radicle explants of cv. Cakmak ranged from 3.8-8.90 and 1.0-8.40, respectively. The number of somatic embryo induced maturing shoots on $\mathrm{cv}$. Kunduru plumule and radicle explant ranged 1.00-9.20 and 0.80-8.00, respectively. Maximum number of somatic embryo induced maturing shoots on plumule and radicle explant of cv. Çakmak were noted on $5 \mathrm{mg} / \mathrm{L} 2,4-\mathrm{D}$. The results further indicated that plumule and radicle explant of both cultivars favored embryo fusion at 3 and $4 \mathrm{mg} / \mathrm{L}$ 2,4-D. These shoots were not strong and showed weak distinctly arrested, hyperhydric growth. Multiple shoots were also noted on fused somatic embryos developed on plumule explant of cv. Cakmak at $2 \mathrm{mg} / \mathrm{L}$ 2,4-D (Figure 2(e), 2(f)). Maximum number of somatic embryo induced maturing shoots on plumule explant of cv. Kunduru were also noted on $6 \mathrm{mg} / \mathrm{L} 2,4-\mathrm{D}$. Maximum number of shoots per explant on radicle explant of cv. Kunduru were noted on $1 \mathrm{mg} / \mathrm{L} 2,4-D$. Irrespective of cultivar radicle explants did not induce embryo fusion with visible single somatic embryo induced maturing shoots (Figure 2(g)). As tissue cultured plants have difficulties during acclimatisation to external environment, the plantlets were maintained in the culture boxes for 10 days to allow visible growth and development of roots.

When the plantlets were transferred to peat moss beds in the mist house, they showed 96 and $80 \%$ acclimatisation on plumule and radicle induced plants, respectively, in 2 weeks time. After 7 days from weaning, these plants were transferred to the shade house to grow and set flowers. Water spray containing $0.50 \mu \mathrm{g}$ of NPK $(1: 1: 1)$ was given at intervals of 4 days to enhance success rate of acclimatised plants.

These plants began to show flowering spikes tillering shoots originating from coleoptile nodes after 41-43 days of initial culture. They induced blooming after 5-6 days of being in the shade house (46-48 days post initial culture). Wheat is a self pollinating crop and these spikelets had no difficulty in setting seeds. Plants bore 12-14 healthy normal seeds per spike and were morphologically similar to the seeds obtained on non-tissue cultured plants (57-60 days post initial culture).

\section{DISCUSSION}

Highly efficient and reliable tissue culture protocols are needed to provide a better platform for improvement in wheat. Most of the previous protocols described earlier are based on mature or immature wheat embryos that document competence of two explants for tissue culture and morphogenesis based on cultivar and tissue regeneration. Both plumule and radicle explants isolated from mature wheat seeds have unlimited availability and are independent of growth season restrictions.

Although there are number of reports on the use of plumule explants in other plants like Cocos nucifera (Chan et al. 1998; Hornung 1995) and sorghum (Aher

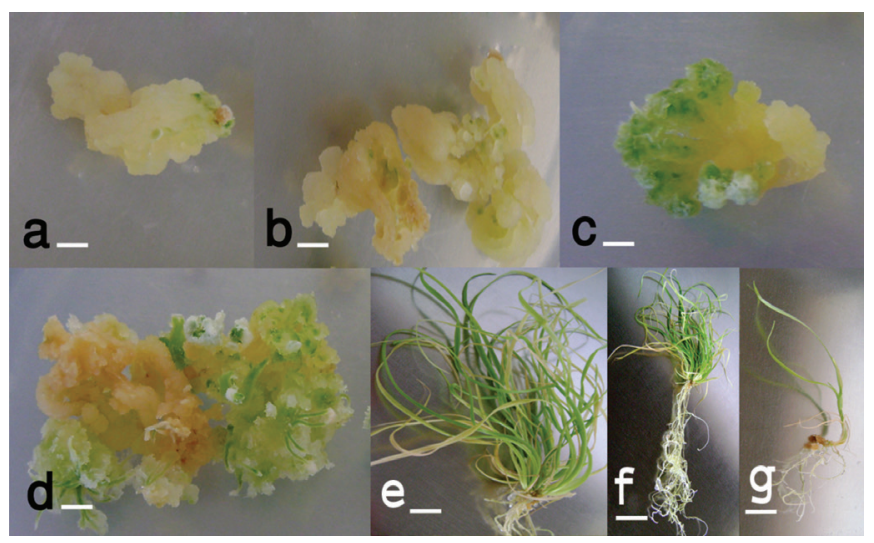

FIGURE 2. Somatic embryogenesis in wheat cultivars and Kunduru (a) Variable number of visible somatic embryos with shoot buds noted on calli of cv. Cakmak and (b) cv. Kunduru (c, d) multiple shoots buds noted on somatic embryos developed on plumule explant of cv. Cakmak and Kunduru, (e,f) multiple shoots were noted on somatic embryos developed on plumule explant of both cultivars $(\mathrm{g})$ single shoots noted on somatic embryos developed on radicle explant of cv. Cakmak 
\& Nair 2005); there is no report on shoot regeneration from the plumule and radicle explants of wheat. A review of previous literature suggests variable success in tissue culture of different wheat species using callus of immature embryos (Becker et al. 1994; Elena \& Ginzo 1988; Maddock et al. 1983; Weeks et al. 1993) and mature embryos (Bi et al. 2007; Patnaik et al. 2006).

Both plumule and radicle tissue initiated callus induction are affected by types of explant and plant species used in the study at all concentrations of 2,4-D. Callus weight and gain was cultivar and explant specific and largely inconsistent. Equal amounts of totipotency from different plant cells must not be expected due to variable developmental process involved and the ability of tissues under in vitro conditions due to their variable morphology background that lead to different physiological processes in plumule and radicle explants that lead to different physiological (Finer 2010; Vasil 2008) and morphogenetic developments. Hydrated seeds initiated germination within the seed without allowing radicle to emerge and induced very fast regeneration on 2,4-D containing MS medium. It is assumed that this could be due to increased RNA and protein synthesis with greater ATP availability and faster embryo growth (Mazor et al. 1984) of hydroprimed seeds of both genotypes.

Both plumule and radicle tissues are juvenile tissues that contain meristematic cells that are main targets of plant growth regulator action (Bhaskaran \& Smith 1990; Feher 2006; Vasil 1988). Moreover, external supply of 2,4-D accelerated induction of calli on these explants such that the developmental responses were highly dependent on endogenous and exogenous hormonal concentrations in agreement with Feher (2006). Both explants induced 100\% callusing irrespective of the 2,4-D concentration, the mean fresh callus weight on plumule explant of both cultivars remained higher compared to callus weight induced on radicles along with variation in callus weight due to exogenous supply of 2,4-D. This affected embryogenic callus induction on these explants and subsequently bi polar somatic embryos formation during somatic embryogenesis after passing through morphological and biochemical changes (Quiroz-Figueroa et al. 2006), with no vascular bonds with mother tissues (Mendoza \& Kaeppler 2002). They found that concentration of 2,4-D effects on callus induction and plant regeneration frequencies from mature embryos of wheat (T. aestivum L.). Although in agreement to these observations these reactions resulted in the successful induction of morphogenesis in the formation of somatic embryos that were followed by macroscopic growth with formation of organised structures like roots followed by shoot initials and shoots in chronological order within a short period. The morphogenic response did not stop once the 2,4-D was withdrawn during the first culture on MS medium. The results of this study do not agree with Mendoza and Kaeppler (2002) as far as fresh weight induction is concerned; they noted that callus fresh weight decreased when the concentration of 2,4-D was increased. They also noted that calli plated on $18 \mu \mathrm{M}$
2,4-D were detrimental accompanied with browning and necrosis on $90 \%$ of them. All these differences seem to be due to different wheat cultivars and explants used in the two studies.

The results of this study, showed that it is possible to get regeneration from plumule and radicle explants of wheat and confirmed that the shoot regeneration is considerably affected by the type of cultivar, concentration of plant growth regulator and explant used in the study in agreement with Bregitzer et al. (1998). The results are partially supported by the studies of Balli et al. (1993), in which a maximum regeneration rate occurred with the addition of $2.5 \mathrm{mg} / \mathrm{L}$ of 2.4-D in the regeneration medium. The results are also in line with Chaudhury and Qu (2000) and Mehmood et al. (2013) on different cultivars that infer possibility of callus proliferation and regeneration effeiciency differing significantly among genotypes depending on concentrations of 2,4-D. The tissue cultured plants were morphologically similar to plants raised from seeds bearing $100 \%$ viable seeds. The time needed in somatic embryo based recovering of plantlets from start of culture to transfer to soil is 57-60 days. The study identifies possibilities and strategies for acclimatisation of in vitro regenerated wheat cultivars Cakmak and Kunduru for successful acclimatisation in agreement with previous studies by Parmar et al. (2012). The regeneration and embryogenic ability of wheat plumule and radicle explants varied and showed clear implications of both cultivar and explants on plant ontogenesis. The study reports highly efficient regeneration method that could be used on a large scale for easy multiplication of wheat especially for breeding. This protocol is cost effective and short duration oriented that could help in approaches towards better understanding of wheat cells totipotency expression. Further studies are necessary to understand more specific requirements of plumule and radicle explants for improved regeneration performance. The variable behavior of two explants observed makes it clear that dynamic changes occur in metabolism and cellular physiology that lead to differential behviour of explants. This protocol has the advantage of producing morphogenetic calli and could potentially replace earlier protocols where poor performance of mature embryos has been reported, as different mechanisms could be involved in regeneration from mature embryos and regeneration from mature plumule and radicle explants. It is concluded the regeneration rate reported in this study could be acceptable for use in transformation and breeding studies. Attainment of mature plants in 60 days warrants obtaining 6 generations in one year. The results of this study infer practical importance of using plumule and radicle explants obtained from warm water hydro primed seeds to accelerate breeding and hybridisation in wheat and establishment of lines without dependence on season. This would permit easy application of breeding and genetic transformation in wheat.

Both authors Parisa Pourali Khariz and Mahsa Pourali Khariz contributed equally to this paper. 


\section{REFERENCES}

Aher, R.K. \& Nair, L.N. 2005. Morphogenetic responses of plumule, radicle and cotyledon explants of Sorghum vulgare Pers. in vitro. Asian Journal of Microbiology, Biotechnology \& Environmental Sciences 7: 791-792.

Balli, A.M.R., Rossnagel, B.G. \& Kartha, K.K. 1993.Evaluation of 10 Canadian barley (Hordeum vulgare L.), cultivars for tissue culture response. Canadian Journal of Plant Sciences 73: 171-174.

Becker, D., Brettschneider, R. \& Lorz, H. 1994. Fertile transgenic wheat from microprojectile bombardment of scutellar tissue. Plant Journal 5: 299-307.

Bhaskaran, S. \& Smith, R.H. 1990. Regeneration in cereal tissue culture: A review. Crop. Sci. 30(6): 1328-1337.

Bi, R.M., Kou, M., Chen, L.G., Mao, S.R. \& Wang, H.G. 2007. Plant regeneration through callus initiation from mature embryo of Triticum. Plant Breeding 126(9): 9-12.

Bregitzer,P., Dahleen,L.S. \& Campbell,R.D. 1998. Enhancement of plant regeneration from embryogenic callus of commercial barley cultivars. Plant Cell Reports 17: 941-945.

Chan, J.L., Saenz, L., Talavera, C., Hornung, R., Robert, M. \& Oropeza, C. 1998. Regeneration of coconut (Cocos nucifera L.) from plumule explants through somatic embryogenesis. Plant Cell Reports 17: 515-521.

Chaudhury, A. \& Qu, R. 2000. Somatic embryogenesis and plant regeneration of turf - type bermudagrass: Effect of 6 benzyladenine in callus induction medium. Plant Cell Tissue and Organ Culture 60(2): 113-120.

Chu, C.C., Hill, R.D. \& Brule-Babel, A.L. 1990. High frequency of pollen regeneration in embryoid formation and plant (Triticum aestivum L.) on monosaccharide containing media. Plant Science 66: 255-262.

Elena, B.E. \& Ginzo, H.D. 1988. Effect of auxin levels on shoot formation with different embryo tissues from a cultivar and a commercial hybrid of wheat (Triticum aestivum L.). Journal of Plant Physiology 132: 600-603.

Feher, A. 2006. Why somatic plant cells start to form embryos? In Somatic Embryogenesis, Vol 2, Plant Cell Monographs, edited by Mujib, A. \& Šamaj, J. Berlin: Springer. pp. 85-101.

Fellers, J.P., Guenzi,A.C. \& Talaiferro, C. 1995. Factors effecting the establishment and manitenance of embryogenic callus and suspension cultures of wheat (Triticum aestivum L.). Plant Cell Reports 15: 232-237.

Fennel, S., Bohorova, N., Ginkel, M., Crossa, J. \& Hoisington, D.A. 1996. Plant regeneration from immature embryos of 48 elite CIMMYT bread wheats. Theoretical and Applied Genetics 92: 163-169.

Finer, J.J. 2010. Plant Nuclear Transformation, Vol 64, Genetic Modification of Plants. Berlin: Springer.

Hess, J. \& Carman, J. 1998. Competence of immature wheat embryos: Genotype, donor plant environment, and endogenous hormone levels. Crop Science 38: 249-253.

Hornung, R. 1995. Micropropagation of Cocos nucifera L. from plumuler tissue excised from mature zygotic embryos. Plantations Recherche Developpement 2(2): 38-41.

Maddock, S.E., Lancaster, V.A., Risiott, R. \& Franklin, J. 1983. Plant regeneration from culture immature embryos and inflorescences of 25 cultivars of wheat (Triticum aestivum L.). J. Experim. Bot. 34: 915-926.

Mathias, R.J. \& Simpson, E.S. 1986. The interaction of genotype and culture medium on tissue culture response of wheat (Triticum aestivum L. em. Thell) callus. Plant Cell Tiss. Organ Cult. 7: 31-37.
Mazor, L., Perl, M. \& Negbi, M. 1984. Changes in some ATP dependent activities in seed during treatment with polyethylene glycol and during redrying process. J. Exp. Bot. 35: 1119-1127.

Mehmood, K., Arshad, M., Ali, G.A. \& Razzaq, A. 2013. Tissue culture responses of some wheat (Triticum aestivum L.) cultıvars grown in Pakıstan. Pak. J. Bot. 45(SI): 545-549.

Mendoza, M.G. \& Kaeppler, H.F. 2002. Auxin and sugar effects on callus induction and plant regeneration frequencies from mature embryos of wheat (Triticum aestivum L.). In Vitro Cell. Dev. Biol.-Plant 38: 39-45.

Parmar, S.S., Sainger, M., Chaudhary, D., Pawan, K. \& Jaiwal, P.K. 2012. Plant regeneration from mature embryo of commercial Indian bread wheat (Triticum aestivum L.) cultivars. Physiol. Mol. Biol. Plants 18(2): 177-183.

Patnaik, D., Vishnudason, D . \& Khurana, P. 2006. Agrobacterium - mediated transformation of mature embryos Triticum aestivum and Triticum durum. Curr. Sci.91(3): 307-317.

Patnaik, D. \& Khurana, P. 2001. Wheat biotechnology: A minireview. Electronic J. Biotechnol. 4: 74-102.

Rajyalakshmi, K., Grover, A., Maheshwari, N., Tyagi, A.K. \& Maheshwari, S.C. 1991. High frequency regeneration of plantlets from the leaf bases via somatic embryogenesis and comparison of polypeptide profiles from morphogenic and non-morphogenic calli in wheat (Triticum aestivum L.). Physiologia Plantarum 82: 617-623.

Santacruz-Ruvalcaba, F., Gutiérrez-Mora, A. \& Rodríguez-Garay, B. 1998. Somatic embryogenesis in some cactus and agave species. Journal of the Professional Association for Cactus Development 3: 15-26.

Sarker, R.H. \& Biswas, A. 2002. In vitro plantlet regeneration and Agrobacterium-mediated genetic transformation of wheat (Triticum aestivum L.). Plant Tissue Cult. 12: 155-165.

Snedecor, G.W. \& Cochran, W.G. 1967. Statistical Methods. Iowa: The Iowa State Univ. Press. pp. 327-329.

Vasil, I.K. 2008. A history of plant biotechnology: From the cell theory of Schleiden and Schwann to biotech crops. Plant Cell Rep. 27: 1423-1440.

Vasil, I.K. 1988. Progress in the regeneration and genetic manipulation of cereal crops. Biotechnology 6: 397-402.

Vasil, I.K. 1994. Molecular improvement of cereals. Plant Mol. Biol. 25: 925-937.

Weeks, J.T., Anderson, O.D. \& Blechl, A.E. 1993. Rapid production of multiple independent lines of fertile transgen wheat (Triticum aestivum L.). Plant Physiol. 102: 1077-1084.

Department of Field Crops

Faculty of Agriculture, Ankara University

06110 Dışkapı, Ankara

Turkey

*Corresponding author; email: mahsapourali7@gmail.com

Received: 5 November 2014

Accepted: 22 April 2016 